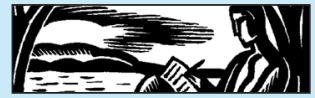

\title{
Beyond the Subject: Anglo-American Slave Narratives in the Netherlands, 1789-2013
}

\author{
Marijke Huisman
}

Utrecht University/VU University

\section{ABSTRACT IN ENGLISH}

In recent years life writing scholars have increasingly linked the autobiographical genre to human rights causes, such as abolitionism. This article aims to historicize and contextualize the presupposed connection between human rights and the human subject of autobiographical discourse by focusing on the cultural mobility of Anglo-American slave narratives. Tracing their presence in the Netherlands since the late eighteenth century, it is demonstrated that slave narratives were considered of no value to Dutch abolitionism and Dutch debates on slavery and its legacy until very recently. Publishers and readers did, however make sense of slave narratives as sensational, gothic literature. Furthermore, the narratives were appropriated by Dutch fundamentalist Protestants advocating the nation's emancipation from its state of spiritual "slavery". Only when secularization converged with post-colonial migration patterns new interpretations stressing Black experience, agency, and subjectivity came to the fore in the Netherlands. Inspired by African-American rhetoric, Afro-Dutch migrants appropriated slave narratives in order to break the public silence on the Dutch history of slavery.

\section{ABSTRACT IN DUTCH}

Het autobiografisch genre wordt sinds de eeuwwisseling door steeds meer onderzoekers gekoppeld aan mensenrechtenbewegingen, zoals de antislavernijbeweging. Dit artikel historiseert en contextualiseert de veronderstelde relatie tussen mensenrechten en het menselijk subject door de culturele mobiliteit van Anglo-Amerikaanse slavenautobiografieën te onderzoeken. Sinds de late achttiende eeuw verschijnen er in Nederland uit het Engels 
vertaalde slavenautobiografieën, maar die werden destijds niet relevant geacht voor de Nederlandse anti-slavernijbeweging. Tot voor kort werden deze autobiografieën evenmin betrokken in historische debatten over slavernij en de erfenis daarvan. Uitgevers en lezers begrepen slavenautobiografieën veeleer als sensationele gruwellectuur. Inhoudelijk werden deze autobiografieën vanaf het midden van de negentiende eeuw bovendien toegeëigend door orthodoxprotestanten die de natie wilden bevrijden van haar geestelijke 'slavernij'. Pas in de late twintigste eeuw, toen secularisering en ontzuiling samenvielen met post-koloniale migratiepatronen, ontstond er aandacht voor de 'zwarte ervaring' met slavernij en werden slavenautobiografieën in termen van zwarte subjectiviteit en mensenrechten gelezen. Met behulp van Afro-Amerikaanse retoriek slaagden Afro-Nederlanders er na de eeeuwwisseling ten slotte in om nationale erkenning af te dwingen voor het koloniale slavernijverleden.

Keywords: slave narratives; slavery; cultural mobility; the Netherlands

\section{INTRODUCTION}

Starting with Die Geschichte der Autobiographie (1907), by German philosopher-historian Georg Misch, critics have related the autobiographical genre to the individual human subject. First conceptualized as a "great, white man," the "human subject" was stretched, in the course of the twentieth century, to include male and female subjects from all colors and classes. Indeed, the democratic expansion of the autobiographical genre has taken such a route that some do not fail to scorn "life writers" for their focus on "the depraved people of the earth" (Renders 2013, 201). Recently, moreover, life writing scholars have connected the human subject of autobiographical discourse to the notion of human rights (Schaffer and Smith 2004; Whitlock 2007; Jensen and Jolly 2014). "[T] he right to write our life stories is a natural extension of the right to life, liberty, and the pursuit of happiness," Paul John Eakin $(2001,113)$ has proclaimed, whereas Margaretta and Richard Jolly assert that the autobiographical genre and the struggle for human rights are historically "intertwined phenomena" and "symbiotic outgrowths of Enlightenment legacies" (2006, 780). From that perspective slave narratives, like the famous Interesting Narrative of the Life of Olaudah Equiano, or Gustavus Vassa, the African, Written by Himself (1789), mark the beginning of a long tradition that links personal storytelling to struggles for humanity and human rights.

In this article I want to problematize the individual human subject and its quest for rights and recognition as central subjects of autobiographical discourse. My studies in the marketing and reception of autobiographical texts show that nineteenth-century book publishers and critics tended to 
concentrate on the thematic contents of life narratives, not on the individual narrators. Contemporaries were interested in, for instance, religious developments described by a minister, or a business man's opinions on the pros and cons of free trade policies (Huisman 2010, 2011). Such findings lead me to question whether the subject of autobiographical discourse has been stable over time. Before jumping to conclusions, it seems worth considering Stephen Greenblatt's (2010) call for studies that focus on cultural mobility and track multiple interpretations or appropriations of cultural products over time and place. I think this programme could be of use in moving beyond generalized presuppositions in the field of life writing too, as I will demonstrate by tracing the readings of AngloAmerican slave narratives in the Netherlands since the late eighteenth century. From what follows it will become clear that whatever Dutch readers found in texts like the Interesting Narrative of the Life of Olaudah Equiano, it was not the human subject striving for recognition and human rights until very recently.

\section{SLAVE NARRATIVES IN CONTEXT}

In the era of Enlightenment and Awakenings, revolutionaries, humanitarians, and evangelical Protestants suddenly expressed their care for enslaved people through organizations like the Pennsylvania Abolition Society (1784), the Society for Effecting the Abolition of the Slave Trade (1787) in Great Britain, and the Société des Amis des Noirs (1788) in France (Brion Davis 2006; Barnet 2013). In order to disseminate their ideas and beliefs about humanity and natural or human rights, abolitionists used the printing press extensively. Sermons, tracts, essays, novels, and other kinds of texts were published to mobilize the reading public against the slave trade and slavery. Generally these texts were written by white men and women, but British and North American abolitionists included ghost-written and self-written autobiographical accounts of former or fugitive slaves in their protest repertoire. Depending on the time period and genre definition, tens, hundreds, or thousands so-called "slave narratives" can be said to have been published in the English language (Starling 1988; Andrews 1986). ${ }^{1}$

The first slave narratives were significantly shaped by the religious discourse of evangelicals who spearheaded antislavery activism. In effect, many slave narratives from the 1770 s and 1780 s drew on the genre of spiritual autobiography, showing that the slave's life "was amenable to the same narratives of transformation and redemption as "everyman's" (Sinanan 2007, 63). For instance, A Narrative of the Most Remarkable 

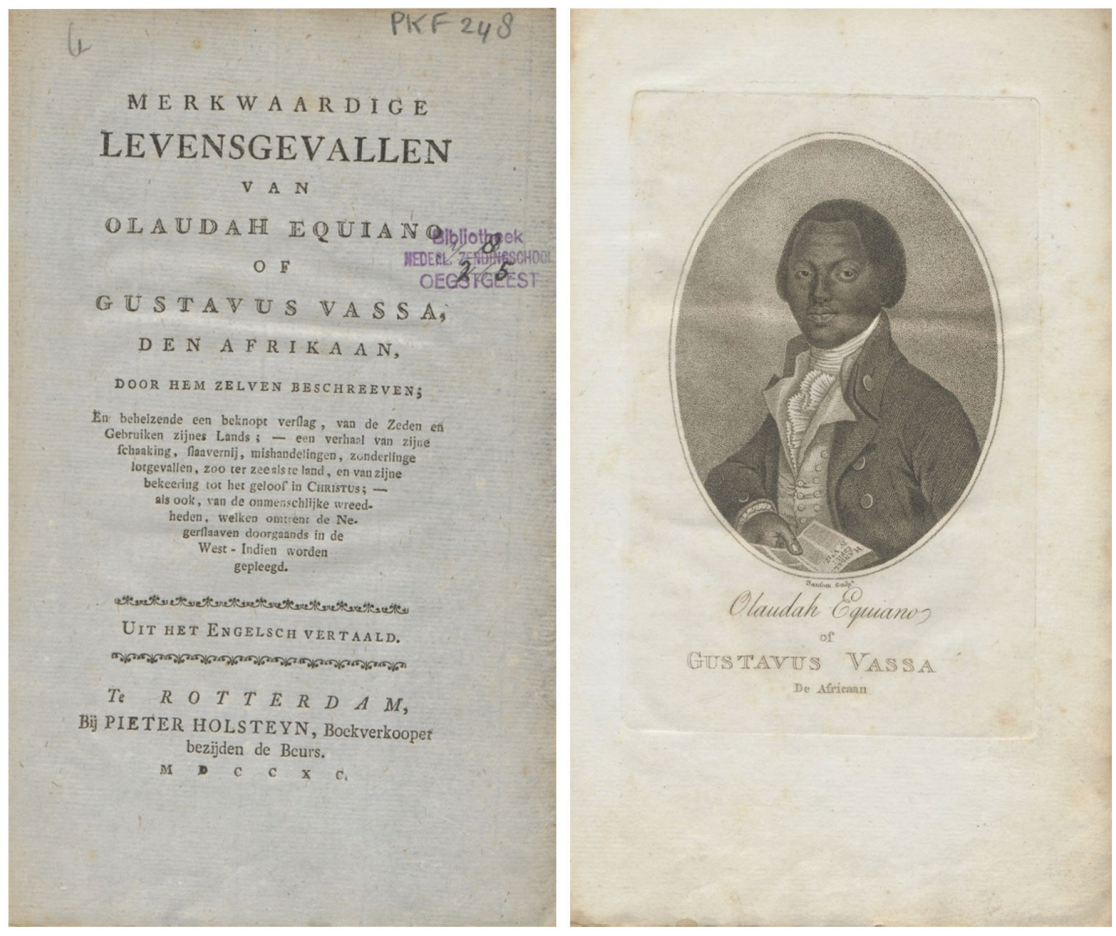

Title page and portrait from the Dutch translation (1790) of The interesting of the life of Olaudah Equiano, or Gustavus Vassa, the African. Written by himself (Londen 1789). Photo: Universiteitsbibliotheek Utrecht.

Particulars in the Life of James Albert Ukawsaw Gronniosaw (1772), integrated a tale of enslavement into a larger narrative on religious conversion from African "heathenism" to Protestant Christianity. A similar storyline structures the Interesting Narrative of the Life of Olaudah Equiano. Posing for the author's portrait with a Bible in hand, Equiano used the preface to express his gratitude for the fact that, as a slave, he had "obtained to the knowledge of the Christian religion" (Sollors 2001, 7), and loaded his narrative with descriptions of his religious thoughts and developments. Consequently, this slave narrative can be read as an allegory of spiritual redemption.

However, the Interesting Narrative cannot be reduced to a spiritual autobiography. Equiano drew on many more genres. The first chapter on the customs and circumstances in the African kingdom Eboe, where Equiano claimed to be born, is reminscent of a geographical description. Echoes of the sentimental novel, the travel book, and the adventure story can be 
found in Equiano's narrations of him being kidnapped into slavery and his subsequent career as a sailor, whereas the parts of the book relating Equiano's experiences, observations, and thoughts on slavery can be considered as testimony, economic treatise, or political petition. The latter generic influence also shows in the preface, in which Equiano explains the purpose of his work. Addressed to the members of the British Parliament, he wrote that the "chief design" of his narrative was "to excite in your august assemblies a sense of compassion for the miseries which the Slave-Trade has entailed on my unfortunate countrymen" (Sollors $2001,7)$. As if to lend weight to this autobiographical petition, Equiano included a list of over three hundred subscribers who had supported the publication of his book.

It was not until 1807 that the British ended the slave trade, and until 1833 that they ended slavery, but the Interesting Narrative became an immediate success. Nine different editions were published in the United Kingdom before the author's death in 1797 (Carretta 2006, 335-62). An American edition (1791) was issued by New York publisher William Durell, who specialized in Protestant literature (Green). In the United States the book was not reprinted for some three decades, but it was rediscovered by some of the evangelicals who relaunched the abolitionist movement through organizations like the American Anti-Slavery Society (AASS 1833). Lydia Maria Child, for instance, included a summary of Equiano's life in the chapter on the "Intellect of Negroes" in her Appeal in Favor of that Class of Americans Called Africans (1833), and abolitionist publisher Isaac Knapp issued a second edition of the complete text in 1837. By that time, however, American abolitionists were in need of other types of literature to support their cause. "The North is so blinded it will not believe what we say about slavery, its horrors", wrote AASS secretary Theodore Weld in 1837 (Williams 1986, 302). Antislavery activists therefore set themselves the task of providing realistic and detailed evidence of those horrors to the "court of public opinion" (DeLombard 2007; Gould 2007, 19). From then on, slave narratives were instrumental in exposing the harsh realities of slaves' lives and supplying the general reading audience with truthful evidence against the Southern plantation system and its pro-slavery representatives.

Religion remained an important part of abolitionism, but the antebellum American slave narrative somewhat secularized. This trend can be illustrated by the Narrative of the Life of Frederick Douglass, an American Slave, Written by Himself (1846), sometimes described as the slave narrative par excellence (Gates 1987, 6). Douglass did not pose with a Bible for his portrait, nor did he dwell in the narrative on his religious development. Instead, Douglass described his journey from slavery to freedom through 
descriptions of his efforts to become literate as well as his physical resistance. He drew on republican discourse, quoted Founding Fathers like Patrick Henry, famous for his statement: "Give me Liberty, or Give me Death" (74), and listed all sorts of cruelties that had been done to him and his fellow-slaves by men who pretended to be pious Christians. In an appendix, however, Douglass took up the religious theme in another manner. He claimed not to be against religion as such, and agreed with the AASS argument that "the pure, peacable and impartial Christianity of Christ" was not compatible with the "corrupt, slaveholding, womenwhipping, cradle-plundering, partial and hypocritical Christianity of this land" (97) in order to clarify that every "true Christian" should support the abolitionist cause.

In the mid-nineteenth century Douglass's narrative sold over 30,000 copies in the United States and Great Britain, and other slave narratives were very popular, too (Nichols 1959, 150; Andrews 1996, 8, 21; Gould 2007, 21). Some narratives also reached audiences beyond the English language zone. Equiano's Interesting Narrative was issued in German (1792) and Russian (1794), while Douglass's Narrative was translated into French (1848). However, the first foreign translations of these two famous slave narratives were printed in the Netherlands, in 1790 and 1846, respectively. This quick turn-over is somewhat surprising, because the Netherlands is not particularly known for its abolitionism (Kuitenbrouwer 1995; Drescher 1995; Janse 2007; Nimako and Willemsen 2011). There was no organized anti-slavery movement until 1853, and slavery played virtually no part in Dutch historical culture until the turn of the twenty-first century. Nonetheless, slave narratives were printed in the Netherlands - both before and after the abolition of slavery in its Caribbean colonies (1863). Why did these books appear in the Netherlands, and how did these narratives work there? In the remainder of this article I will analyze the production and reception of slave narratives in the Netherlands from 1789 until the present.

\section{THE NON-VALUE OF SLAVE NARRATIVES TO DUTCH ABOLITIONISM}

In 1792, on the penultimate page of the fifth, revised edition of The Interesting Narrative of the Life of Olaudah Equiano, or Gustavus Vassa, the African, Written by Himself, the author reported having met "persons of note from Holland and Germany, who requested me to go there; and I was glad to hear that an edition of my Narrative had been printed in both places" (Carretta 1995, 235). The identities of these "persons of note" are unknown, but the Dutch edition (1790) of Equiano's narrative was published by Pieter Holsteijn. In his preface the Rotterdam-based printer 


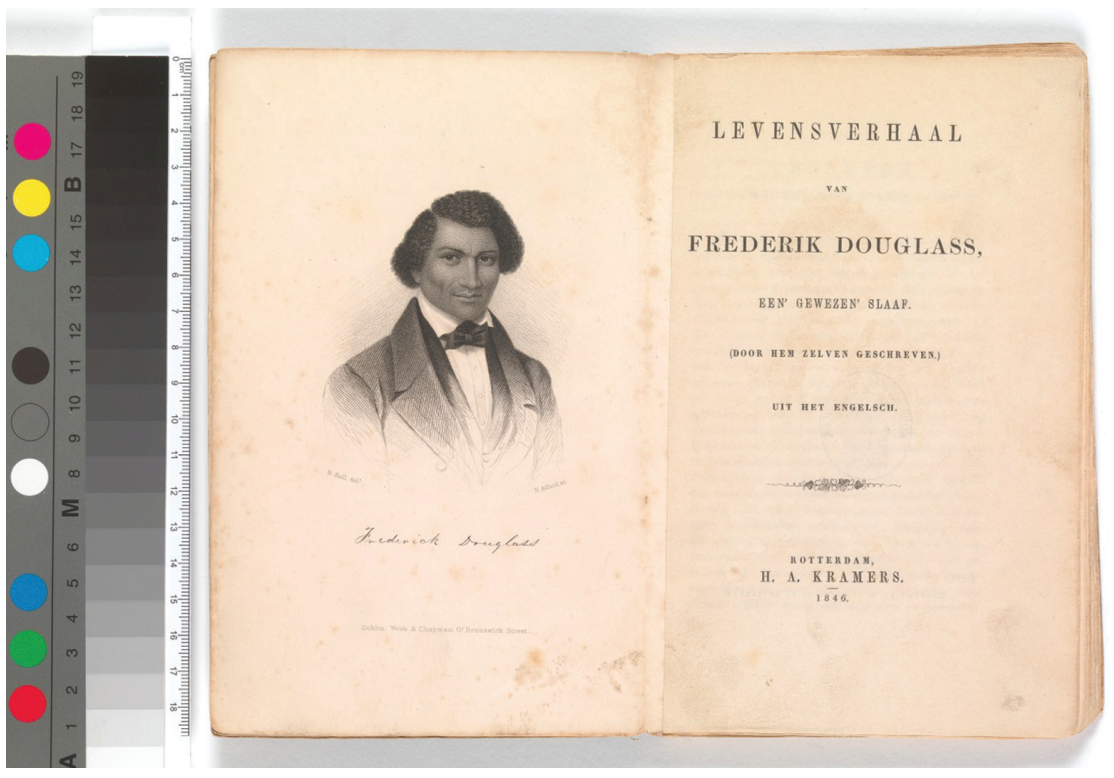

Title page and portrait from the Dutch translation (1846) of Narrative of the life of Frederick Douglass, an American slave. Written by himself (Boston 1845). Photo: Koninklijke Bibliotheek, Den Haag.

explained how he had learned about Equiano's book through reviews in "the best of English magazines". He decided to produce a translated edition, because he knew Dutch readers to be fond of "the lives, and interesting adventures of important persons". Being a "Negro slave", Equiano obviously could not pass for an "important person", but Holsteijn reasoned that the Dutch audience would like to read about Equiano's many adventures, his conversion to Christianity, and his descriptions of Africa and Africans. Especially interesting to Holsteijn was the way in which the narrative could serve as evidence that "despised and mistreated Negroes are not immune to education" (Holsteijn 1790 n.p.).

As elsewhere in the Western world, the slave trade and slavery subjects were subjects of public debate in the Dutch Republic. "Is there any subject more than worthy of the attention of Philanthropes, it is certainly the cause of Negro slaves," according to leading magazine Algemeene Vaderlandsche Letter-Oefeningen in $1791 .^{2}$ Holsteijn, in his preface, took up this cause by presenting Equiano's narrative as proof against prejudices about the supposedly unintelligent, and hence subhuman, quality of Black people. In this, Holsteijn followed the lead of English critics who considered Equiano's self-written narrative as a substantial demonstration 
of Africans' intellectual capabilities (Sollors 2001, 295-7). "W.," in the General Magazine and Impartial Review, also thought of the narrative as a tool for mobilizing moral sentiments: "the reader, unless perchance he is either a West-India planter, or Liverpool merchant, will find his humanity often severely wounded by the shameless barbarity practised towards the author's hapless countrymen in all our colonies" (Sollors 296). In the Netherlands, however, Equiano's one and only critic did not show any sentimental engagement with the former slave and did not relate to the topical debate at all. He summarized the contents of the slave narrative in such a way that it focused on Equiano's travels - both as a slave and a free man - and concluded by proposing that it was a pleasurable means of passing time. ${ }^{3}$

The Dutch critic's reading cannot be explained by the translation; the Dutch edition included Equiano's preface and followed the original text to a large extent. Still, Equaiano's emotional call for compassion may have been difficult to understand in the Netherlands. While moral sentiments played a large role in British politics and British abolitionism in particular, Dutch political culture was shaped by a formal, governmental style (Rijn 2010; Janse 2007, 12-21). Dutch variations of the sentimental novel, moreover, aimed not at the arousal of emotional engagement with all kinds of victims, but at the religious education of the reader (Meijer 1998, 344-9). There was also a major difference regarding the specifics of the political debate about slavery. While the British scene was dominated by a moral fight between pro- and anti-slavery arguments, more central to the Dutch was the technical problem of how to pay for emancipation. As to form and contents, then, Equiano's narrative may have fallen onto barren ground in the Netherlands. Perhaps the only way in which this text could be understood by Dutch readers was as if it were just a travel journey - one of the most popular types of literature at the time (Kloek and Mijnhardt 1988, 59, 62-3).

Equiano did not respond to the invitation to visit the Netherlands, which he mentioned in the 1792 edition of his autobiography. He was probably busy rescuing his reputation, because in April 1792 English newspapers reported that Equiano was born on the island of Santa Cruz, and had not been kidnapped from Africa. Ever since, his figure has been surrounded by questions regarding his identity - and the narrative's authenticity (Carretta 2006, 351-4, 2007; Lovejoy 2006). Not so much in the Netherlands, however. Besides the one edition of his book, a few newspaper advertisements, and the one review, Equiano left no mark on Dutch print culture. Slavery and the slave trade, on the other hand, were recurrent themes in public debate (Paasman 1984; Sens 2001), especially during the era of the Batavian Republic (1795-1806). In 1797, revolutionary Pieter Vreede even proposed abolishing slavery in the Dutch colonies, 
but his proposition was not put to the vote. No arguments of principle were raised in the newly founded National Assembly, only practical ones, in particular that the poor economic situation of the Batavian Republic made it impossible to compensate slave owners for loss of their property.

The Dutch became stuck in financial deliberations for decades, but foreign interventions brought some progress to the abolitionist cause. In 1814, the British pressured the newly founded Kingdom of the Netherlands to end the slave trade, and again in the early 1840 English abolitionism played a role in the course of Dutch events. Delegates from the British and Foreign Anti-Slavery Society visited the Netherlands in 1840 and 1841, resulting in the formation of a number of local anti-slavery associations. Liberal abolitionist men from the city of Rotterdam also tried to lauch a national group, but orthodox Protestant abolitionists from The Hague objected to the proposed organization's secular profile. Nonetheless, several groups sent anti-slavery petitions to King Willem I in 1842. Responding to these requests, J.C. Baud, Secretary of Colonial Affairs, reported that the government was in favor of emancipation, but he raised practical problems that foreclosed immediate action: the kingdom could not afford to compensate slave owners, and slaves were not yet ready - "neither intellectually nor morally" - to live a free life (Lenders 1996, 216; Janse 2007, 69). In addition, he explained to the abolitionist petitioners that a delicate topic such as emancipation could best be discussed in private, and urged them not to raise the matter in public again (Reinsma 1963, 52).

Despite Baud's call for privacy, slavery was discussed in public during the 1840s. From 1844 until 1847 a group of liberal abolitionists published the journal Bijdragen tot de kennis der Nederlandsche en vreemde koloniën, bijzonder betrekkelijk de vrijlating der slaven [Contributions to the Knowledge of Dutch and Foreign Colonies, Especially with Regard to the Emancipation of Slaves], and around the same time the Narrative of the Life of Frederick Douglass was translated into Dutch. Levensverhaal van Frederik Douglass, een gewezen slaaf (Door hem zelven beschreven) was printed by H.A. Kramers, also a Rotterdam-based publisher. We have no records informing us about his motives, but it is possible that Kramer's engagement with the abolitionist cause was awakened by the delegates of the British and Foreign AntiSlavery Society, or the Rotterdam circles of abolitionists. In any case, in his text advertising the book he expressed the wish that Levensverhaal van Frederik Douglass would "raise public interest for the plight of Slaves, of whom so many are situated in the Dutch colonies as well."

Douglass's narrative was reviewed in a number of journals. The editors of the abolitionist journal Bijdragen spent seven pages discussing Douglass's life story, but their verdict was far from enthusiastic. ${ }^{5}$ On the one hand, they acknowledged the book's success in Great Britain and 
America, and wished that this "readable text" could help to spread among the Dutch too "the contention that slavery cannot be condoned or protected by any enlightened and godly nation." On the other hand, the editors were not very positive about the contents of the book. Compared to an essay "On the Situation of Negro Slaves in the United States of America," published in a previous volume of the journal, Douglass did not mention "cruelties and horrors" that were yet unknown. His argument that slavery was un-Christian was neither new nor innovative. The editors, therefore, wondered about the text's actual relevance. According to them, it was interesting to see that it was written by a "Negro" himself, but otherwise this "Negro author" did not bring anything noteworthy to the Dutch abolitionists' table.

British and American critics were much more favorable to Douglass's life story (Ripley). ${ }^{6}$ They praised his work as an "excellent piece of writing" that reminded them of the rhetorical skills of acclaimed writers such as John Bunyan and Daniel Defoe. ${ }^{7}$ Moreover, many perceived Douglass's literacy as a strong argument for the humanity of slaves, and thus against slavery. In the Netherlands, the fact that Douglass had written his own narrative was considered to be no reason for applause or special interest. Dutch abolitionists did not consider a slave's perspective particularly relevant to the emancipation debate. Another Dutch critic, writing for a nonabolitionist magazine, even argued that Douglass's personal account did not add anything of value to the discussion. According to him, Douglass reasoned "in the language of self-interest and partisanship." Pointing to the Irish famines and the freedom of "so many Irish" to die from "misery and want," the critic continued to argue that slaves at least were assured of food, and called for a much more "calm" deliberation on slavery and emancipation. ${ }^{8}$

As in 1790, Dutch readers were incapable of connecting the autobiographical genre to the slavery debate. This makes sense when one takes into account the nature of the debate. Since the late eighteenth century, the central question was not so much the moral evaluation of the slavery system or the humanity of Black people, but the funding of emancipation. According to the Dutch, this required a harmonization between slaves' rights to freedom and slave owners' property rights. Personal accounts of fugitive slaves like Douglass - who, by fleeing, had not respected their owner's property rights - were therefore of very little use. The fact that this position was even taken by Dutch abolitionists also shows their specific style of protest. They did not aim to mobilize the masses, as did their Anglo-American counterparts, but adhered to a political culture that conceived politics as the domain of a small elite of reasonable and objective men looking for governmental solutions to technical problems. In this 
respect, it is telling that the Bijdragen-abolitionists refused to follow the lead of the British and Foreign Anti-Slavery Society. Again and again, the Dutch objected against mass petitions and other features of the English protest style. "Our aim must be to work on public opinion by well-studied tracts," wrote a Dutch abolitionist from the Bijdragen circle in 1844 (Janse $2007,82,31-2)$. Slave narratives were obviously considered too subjective or "partisan" to pass for such tracts, which made them all the more useless for the technical debate on how to pay for abolition.

\section{MONEY, SENSATION, AND THE APRIL MOVEMENT (1853)}

Notwithstanding the ambiguous and negative reviews, slave narratives continued to appear on the Dutch book market. In 1850 a translation of the Narrative of William Wells Brown, an American Slave, Written by Himself (1849) was issued, and more were to follow in the era between January 1853, when the Dutch translation of Harriet Beecher Stowe's novel Uncle Tom's Cabin was issued, and the abolition of slavery in the Dutch colonies in $1863 .{ }^{9}$ During this decade public anti-slavery sentiment grew stronger, and in April 1853 the small, local groups of abolitionists finally managed to join forces under the umbrella of the Nederlandse Maatschappij ter Bevordering van de Afschaffing der Slavernij [Dutch Society to Stimulate the Abolition of Slavery]. Later that year, the Secretary of Colonial Affairs even installed a State Commission to study the means to realize the emancipation of slaves in the Caribbean. Because the commission did not produce a viable plan to reconcile the right to freedom with the right to property, political deliberations dragged on for years and the public's interest waned. Five bills were rejected before, on 9 July 1862, Parliament agreed to abolish slavery in the Caribbean as of 1 July 1863. Profits from the economic exploitation of the Netherlands Indies (Indonesia) were used to pay 12 million Dutch guilders to compensate slave owners.

Dutch abolitionists never engaged with the translation and/or production of slave narratives published between 1853 and 1863. What factors, then, explain the appearance of these books in the Netherlands at this time? One answer lies in the specifics of the Dutch book business. Since authorial fees grew increasingly costly in the course of the nineteenth century, publishers took advantage of the lack of any international copyright law. Not paying foreign authors made it possible to reduce costs and still provide the Dutch audience with a broad variety of literature. This means that translating became an important business strategy for nineteenth-century Dutch publishers. To give an indication: in 1850 some 45 percent of the total book production in the Netherlands was comprised of 
translations (Huisman 2012, 59; Huisman 2015). Foreign bestsellers were favorable, of course, and the huge commercial successes of slave narratives may well explain the Dutch editions. From that perspective, it seems to be no coincidence that the Dutch edition of William Wells Brown's narrative appeared with a publisher's footnote indicating that the book had sold over 11,000 copies in England..$^{10}$

Another answer to the question why slave narratives were present on the Dutch book market is the fact that slave narratives could be appropriated for other than abolitionist purposes. As the American abolitionist poet John Greenleaf Whittier had already written in his preface to the Narrative of James Williams, An American Slave who was for Several Years a Driver on a Cotton Plantation in Alabama (1838), the "details of this painful narrative" could attract those "who feel a morbid satisfaction in dwelling upon the history of outrage and cruelty" (Williams, 1838, xx). In the first half of the nineteenth century, such sensationalist readers were on the rise in the Netherlands. They enjoyed works like J.B. Christemeijer's much reprinted Belangrijke tafereelen uit de geschiedenis der lijfstraffelijke regtspleging en merkwaardige bijzonderheden uit de levens van geheime misdadigen [Important Scenes from the History of Corporal Punishment and Interesting Particularities from the Lives of Secret Criminals] (1819). In the 1840 s, publisher A.C. Kruseman even witnessed a "whole series of sensational books" (Kruseman 1886-7: I 215-6), whereas novelist Jan de Vries described the public's interest in gothic literature in a famous scene involving a commercial library in the $1850 \mathrm{~s}$ :

\footnotetext{
"Hebt u ook de Geheimenissen van Udolpho, of wel de Italiaan, of de Biechtstoel der zwarte Boetelingen van Radcliffe, of eenige andere ijsselijke geschiedenisse; maar ze moet wel ijsselijk, razend, erg akelig zijn" vroeg eens een lieve meid, die luchtig den winkel kwam binnenstappen, aan Octavius. "Zijt ge dan zoo groot liefhebster om ijsselijke geschiedenissen te lezen?" vroeg de houder der bibliotheek.

"Jongen ja, Mijnheer, maar het moet zeer afgrijselijk zijn." (Andeweg 25).
}

\footnotetext{
"Do you have The Mysteries of Udolpho, or The Italian, or The Confessional of the black penitents by Radcliffe, or any other gothic story; but it has to be horrific, gruesome, very dreadful" a sweet young girl once asked Octavius when she entered his shop.

"Do you like to read gruesome stories that much?" the librarian asked. "Yes, Sir, but it must be atrocious."
}

Showcasing realistic scenes of violence against slaves, slave narratives could easily be sold and read as sensational or gothic horror books. 
Sensationalist, gothic readings of slave narratives were not particularly Dutch (Fisch 2004, 98-9), but these texts were appropriated for a cause that was. This is evident from the fact that a small wave of slave narratives was published from April 1853 onward. As indicated, the Nederlandse Maatschappij ter Bevordering van de Afschaffing der Slavernij was founded in April 1853. In Dutch history, however, this month is better known for the April Movement: a massive protest movement of Protestants rejecting the liberal government's decision to restore the Catholic Church in the Netherlands. According to thousands of protesters, this policy undermined the Protestant character of the nation, and the April Movement turned out to be the start of a larger project to re-Protestantize the nation (Houkes 2009). In this particular context, Anglo-American slave narratives were used to spark a cause that linked "slavery" to a specific discourse about Dutch identity that stemmed from the seventeenth century.

During the Dutch War of Independence (1568-1648), Protestants made sense of their struggle against the Catholic king of Spain through analogies with the Biblical story of the Jews' exodus from slavery in Egypt. Poet Joost van den Vondel, for instance, compared Philips II to the Egyptian pharaoh in his epic "Pascha" (1612): "The one brings slavery to Jacob's house; the other offers tiranny to the Dutch" (Schama 114). Once the Dutch Republic was established, it was commonplace among Protestants to interpret both their hard-won indendence and economic prosperity as proof that God had selected the Dutch Reformed as his "second people of Israel" (Schama 1989, 132-3; Groningen 1996). Over time the second Israel notion was expanded to the Dutch people at large (Schutte 2000, 88-90), which made the idea of resistance against "slavery" a central theme in Protestant narratives of national history. Protestant historian Guillaume Groen van Prinsterer, for example, compared the Dutch resistance leader Willem van Oranje to Moses, because, "As a Moses, he has led the Reformed, who suffered from deadly suppression, out of the house of slavery" $(1875,105)$.

Since the welfare of the Dutch nation was supposed to be linked to its religious course, fundamentalist Protestants always worried about signs of religious decline. Supporters of the Dutch Réveil (Awakening) called for spiritual restoration from the early nineteenth century on, but their numbers were small. In 1849 only 1.3 percent of the Dutch identified as orthodox or fundamentalist Protestant, but in 1900 the group consisted of one-third to one-half of the population (Houkes 2009, 15). The April Movement was crucial to that increase. The restoration of the Catholic Church led many moderate Protestants to become orthodox and turned the idea of a rise from "slavery" into a national theme. The April Movement also marked the civil and political proliferation of this religious group. In order to spread the gospel and re-shape Dutch society, numerous new 
organizations were formed - from orthodox Protestant publishing houses to Sunday schools, and social reform groups that aimed to emancipate the souls of sinners and savages.

Slave narratives could be of use to the Protestant project, as shown from a new, abbreviated edition of Frederick Douglass's narrative that was published in April 1853. Een slavenleven; of korte levensbeschrijving van eenen Amerikaanschen slaaf, door hem zelven medegedeeld. Toegift op Harriet Beecher Stowe's belangrijk werk: Uncle Tom's Cabin [A Slave's Life; or Short Description of the Life of an American Slave, Reported by Himself, Appendix to Harriet Beecher Stowe's Important Work: Uncle Tom's Cabin] was printed by J.H. Zitman in Leiden, a publisher who specialized in orthodox Protestant and evangelical works. In his preface, editor J.A. Groen made it very clear that real-life slavery was not his primary interest. Notwithstanding some remarks about slavery in America and the Caribbean parts of the Dutch kingdom, Groen focused on the Protestant character of British abolitionism and "moral heroes" such as William Wilberforce. In addition, Groen presented Douglass's narrative to support his view that "true freedom" could not be found in civil and political rights. In order to overcome slavery, one had to accept the eternal truths of Jesus Christ. From his last lines, it becomes clear that this message went far beyond the aim of abolishing slavery in a literal sense:

God ontferme zich over Zijne onderdrukte schepselen en wekke ons op, geene vrijheid zóó hoog te achten als die in Christus Jezus, onzen Heer is, en tegen alles, zelfs tegen de vroomheid, die niet uit Hem is, op onze hoede te zijn. Zijne is de vergelding! Hij zal niet achter blijven met Zijne oordeelen. Zijne genade echter worde meer en meer bekend aan de honderden millioenen, die nog in duisternis verkeeren, hetzij ze Christenen of Heidenen heeten (Groen 1853, 20).

May God have mercy with His suppressed creatures and may He alert us not to recognize any freedom as high as the freedom that is in Christ Jesus, our Lord, and may He protect us against all piety that is not out of Him. His is the retaliation! He will not withhold His judgments. His mercy, however, is becoming ever more known to the hundreds of millions who still walk in darkness, whether they are called Christians or Pagans.

Read in the context of the April Movement, this quote was clearly addressed to Catholics. They had no reason to rejoice in their new-found freedom of religion, according to Protestants like Groen, because Catholics were still "slaves" in the spiritual meaning of the word.

Groen's interpretation was not completely original. His edition of Frederick Douglass's narrative was based on "Ein Sklavenleben," which 
had been published in Missions-Stunden: Neue Sammlung (1851), a collection of missionary reports of the Basel Mission that also considered slavery and emancipation in spiritual and Protestant terms. Such interpretations were foreign neither to Anglo-American abolitionism nor the slave narrative genre. However, in the English language zone statements about spiritual slavery and redemption were (also) used to plead for the ending of real-life slavery in North America and the European colonies. In the German version of Frederick Douglass's abbreviated narrative, on the other hand, slavery was turned into a metaphor for a state of being that could be changed through conversion only. This reading turned out to be particularly useful in the Dutch context of the April Movement,

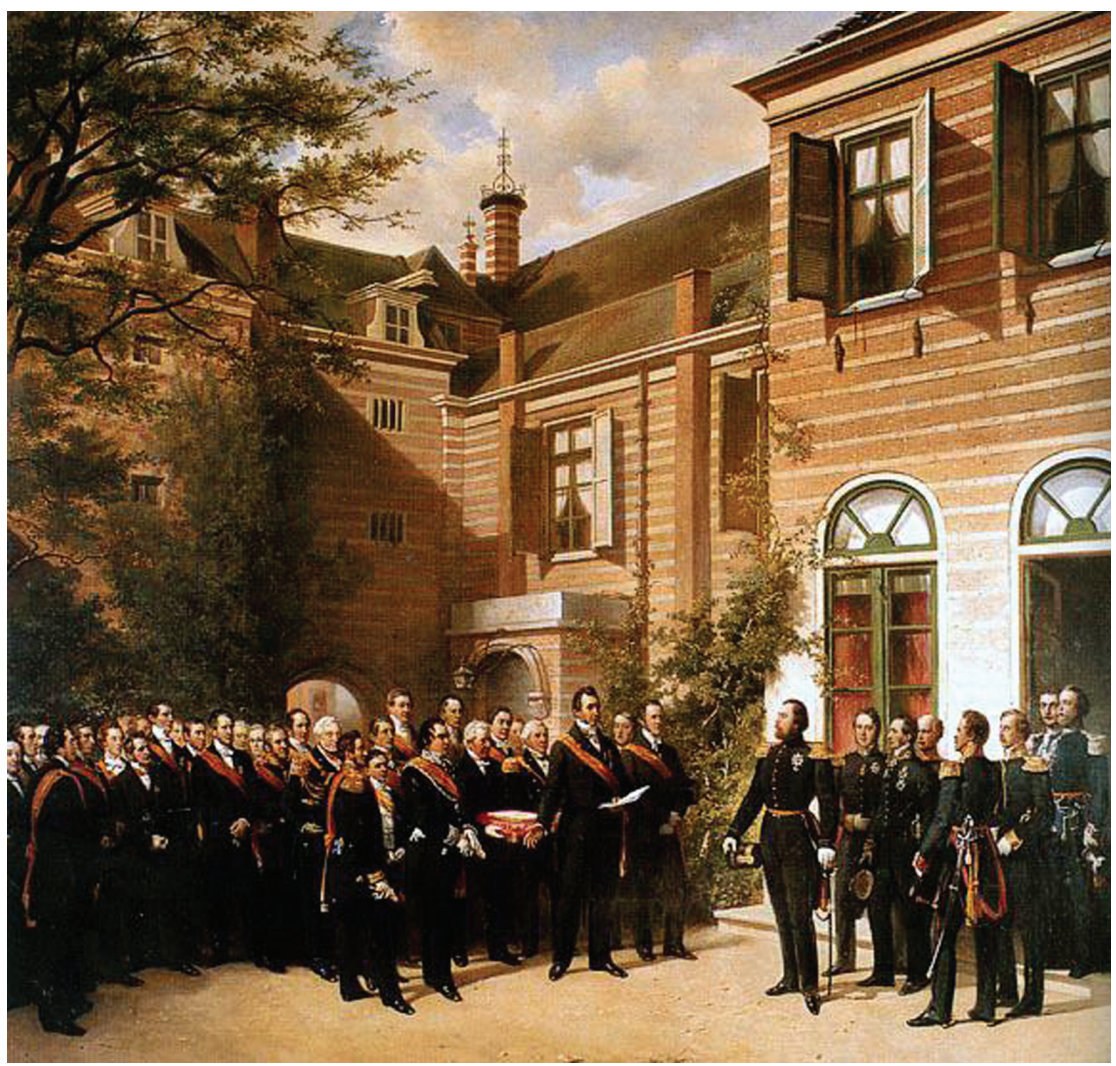

N. Pieneman, April Movement offers its petition against the restoration of the Catholic Church in the Netherlands to king Willem III, 1853. Source: Geheugen van Nederland, http://www.geheugenvannederland.nl/?/nl/items/NCRD01:106610546. 
which aspired to emancipate the Protestant nation from its "spiritual slavery."

\section{UP FROM SLAVERY: PROCESSES OF SPIRITUAL TRANSFORMATION, 1863-1956}

Formally slavery in the Caribbean parts of the Dutch kingdom ended on 1 July 1863, but in practice it continued to exist. In order to safeguard the Surinamese plantation economy, the government had decided to keep the freed slaves of Suriname under state governance for another ten years. This apprenticeship meant that former slaves were free to choose the plantation on which they would spend their lives as wage laborers until 1 July 1873 . Neither the continuation nor the abolition of slavery were much discussed in the Netherlands; the general audience had already lost interest in the slavery debate in the mid-1850s and few newspapers even bothered to report the emancipation of slaves in 1863 (Willemsen 2006, 143-4). However, Protestantism ensured the enduring relevance of slave narratives to the Netherlands.

In 1877, just a few years after the end of state governance, publishing house Het Evangelisch Verbond [The Evangelical Allliance] issued a translation of Josiah Henson's slave narrative. Henson was a very religious man. In 1807, when he was eighteen years old and still a slave, Henson attended a revivalist camp meeting, converted to Christianity immediately, and became a Methodist preacher. Because of his beliefs, he refused to escape from slavery. Instead, he paid his master to set him free. Tricked by the master, however, he ran off to Canada. There he led a settlement of fugitive slaves, and his first narrative - The Life of Josiah Henson, Formerly a Slave, Now an Inhabitant of Canada, as Narrated by Himself (1849) - was published to raise money for the community. In the 1850s Henson became renowned as the real-life model for Harriet Beecher Stowe's novel character Uncle Tom, and the authoress hailed him as a "faithful witness" to "the great Christian doctrine of forgiveness of enemies and the returning of good for evil" (Beecher Stowe, 1858, iii-iv) in her preface to the second, revised edition of the narrative: Truth Stranger than Fiction: Father Henson's Story of His Own Life (1858). Some twenty years later, the Christian Age Office in London published a third edition: Uncle Tom's Story of His Life: An Autobiography of the Rev. Josiah Henson (Mrs. Harriet Beecher Stowe's Uncle Tom), from 1789 to 1876 (1876).

Neither the first nor the second edition of Henson's narrative was printed in the Netherlands, but minister and social reformer C.S. Adama van Scheltema immediately set off to translate the Christian Age Office edition. He firmly framed the narrative in Dutch Protestant discourse. In the preface, for instance, Adama van Scheltema (1877) urges readers to 
read beyond the "surface" and use Henson's tale to estimate whether they were faithful to God and "His religion of Love." Minister Marinus Cohen Stuart, on the other hand, addressed the theme of real-life slavery. In the second preface to the book he proposed that it was obvious "that we Dutch did not do what we owe to our Negroes and coloured people, that the State Emancipation of our former slaves has not been the last word, our debt is not yet paid" (Cohen Stuart, 1877, xxi-xxii). Cohen Stuart did not mean that the Dutch had been wrong to participate in the transatlantic slave trade and the exploitation of Black people through slavery. He meant that they had not done enough to educate their slaves in religious matters. Cohen Stuart, board member of the Nederlandsch Zendelinggenootschap [Dutch Missionary Society], then advanced his point that colonial policy should focus attention on religious education - both in the Caribbean and the Netherlands Indies. For in his mind too, freedom and emancipation meant nothing if it was not accompanied by spiritual redemption.

Within six months over 2,000 copies of Henson's narrative were sold, most likely to the orthodox Protestant constituency of the publishing house Het Evangelisch Verbond. ${ }^{11}$ This was also the probable target audience for the Protestant minister and activist Jan Lodewijk Pierson in the early twentieth century. The reception of his translation of Booker T. Washington's Up from Slavery (1902) indicates, however, that Protestant readings of slave narratives gradually gave way to new interpretations.

Booker T. Washington's life narrative exemplifies the post-Civil War tradition of slave narratives, which focused not so much on the evils of slavery as on the social progress African Americans had made since the emancipation in 1865 (Andrews 2011). Using his own life as an example, teacher and school director Washington stressed the importance of vocational education in order to gain economic independence. In due time, political rights would follow, but that was not his main concern: "I think that the according of the full exercise of political rights is going to be a matter of natural, slow growth, not an over-night, gourd-vine affair" (Washington 236). Reverend Pierson, who advocated state funding for Protestant schools, framed this new type of slave narrative along familiar lines. Returning to the orthodox Protestant version of Dutch national history, he introduced Washington as someone similar to Willem van Oranje because both men had taken up the task of leading their peoples out of slavery (Pierson, 1902, vi-vii). Otherwise, he presented the book as a sequel to "the most moving book ever written": Uncle Tom's Cabin. Reading Washington's narrative, the Dutch audience would be informed about "what happened to all those emancipated slaves" (v).

Up from Slavery was well-received, and many Dutch critics repeated Pierson's statement that it could be read as an epilogue to Beecher Stowe's 
novel. Pierson's reference to the traditional, Protestant narrative of Dutch history, on the other hand, was not echoed. Instead, the reviews indicate that slavery and its legacies had been removed from Dutch history and were perceived as American problems only. One critic also took Washington's narrative as a cue for explicit anti-American statements, because the republic based on the rights to life, liberty, and the pursuit of happiness did not live up to its own standards (Netscher 1902). Most critics, however, interpreted Washington's narrative as a more general story of an exceptional man, a "man of character" who had risen from his disadvantageous position by means of his "power of will, zeal, comprehensive outlook, and simple piety." 12 Compared to previous readings of slave narratives then, Protestantism here seems to have given way to liberalism. In both cases, however, slavery was depicted as a dark background in order to illustrate a spiritual process of transformation - into a faithful Christian, or in this case: into a hard-working "man of character."

Despite the liberal reception of Up from Slavery, Protestant views on slavery continued to dominate the Dutch scene. This can be illustrated by the work of the Protestant poet and historian Jan Willem Schulte Nordholt, who familiarized the Dutch public with the historical background to the Civil Rights Movement through Het volk dat in duisternis wandelt: De geschiedenis van de Negers in Amerika [The People that Walk in Darkness: The History of the Negroes in America] (1956). In a literal sense, this narrative history described African-American history from 1629, when a Dutch ship brought the first African slaves to America, until the Supreme Court's decision overturning school segregation (1954). In Schulte Nordholt's view, however, this was not the real topic of the book. As he explains in the preface:

De geschiedenis van de negers in Amerika is werkelijk toegespitst het verhaal van de spanning tussen de grote dromen van de mensen en hun bittere werkelijkheid, van teleurstellingen maar ook van mogelijkheden, en uiteindelijk van schuld en verzoening, langzamerhand soms gerealiseerd. (Schulte Nordholt 1956, 9)

The history of the Negroes in America is basically the story of the tension between people's great dreams and their bitter reality, of disappointments but also of possibilities, and finally of guilt and atonement, sometimes gradually realized.

Grasping this larger theme, the book's title referred to Isaiah 9.2: "The people that walked in darkness have seen a great light: they that dwell in the land of the shadow of death, upon them hath the light shined." In the Dutch poet-historian's reading, the wandering people in this verse 
were not the Jews or African Americans, but all people. Mankind was gradually but finally approaching the journey's end, according to Schulte Nordholt. In the post-World War II era he witnessed Christians around the world taking social responsibility, which made him optimistic about the immediate future of "equality and freedom and peace" (260). Interestingly, Schulte Nordholt reserved a special place for Booker T. Washington in man's journey towards the light. Contrasting the steady decline of African-American support for Washington's emancipation strategy since the 1910s (Norrell 2009), the Dutch historian devoted his one and only biographical chapter for the man he considered the most important AfricanAmerican leader ever, "a Negro who managed to acquire fame and respect as no other before or since, who was considered the voice of his people by both Negroes and whites alike" (183).

In Schulte Nordholt's optimistic, reconciliatory version of history, slavery was once more reduced to a metaphor for a spiritual state of being, but this explains the success of the book as well. Het volk dat in duisternis wandelt was reprinted four times until 1968, and critics responded positively. Reviewers generally echoed the account, and read the story against the background of recent European history. "The slavery of Negroes together with Hitler's persecution of Jews - must be seen as the worst crime in history," according to one critic, while another asserted that "fascism" was still alive, "even though it is called differently in different places: apartheid in South-Africa or segregation in America."13 Some reviewers mentioned the Dutch role in the transport of enslaved Africans to America, but no references were made to slavery in the Dutch colonies. All attention was focused on the US, but that was relative too. Critics read the book primarily as an illustration of "the power of the Christian religion." How little that narrative was related to any specific historical context is best disclosed by this review's title: "Boek (over negers in VS) dat niet meer loslaat" [Gripping Book (about Negroes in the US)] ${ }^{14}$

\section{POST-COLONIAL PERSPECTIVES: BLACK AGENCY AND PUBLIC RECOGNITION}

In the 1970s, Protestant conceptions of slavery lost ground in the secularizing Netherlands. However, third-worldism was on the rise (Kuitenbrouwer 1994; Hellema 2012, 62-4) and a new edition of Olaudah Equiano's narrative was launched: Equiano"s reizen: Autobiografie van een negerslaaf [Equiano's Travels: Autobiography of a Negro Slave, 1977]. In the preface, anti-apartheid activist and left-wing radio journalist Karel Roskam clearly struggled to frame the book. Based on the number of translations and editions, Roskam suspected it to have been much read in the era around 


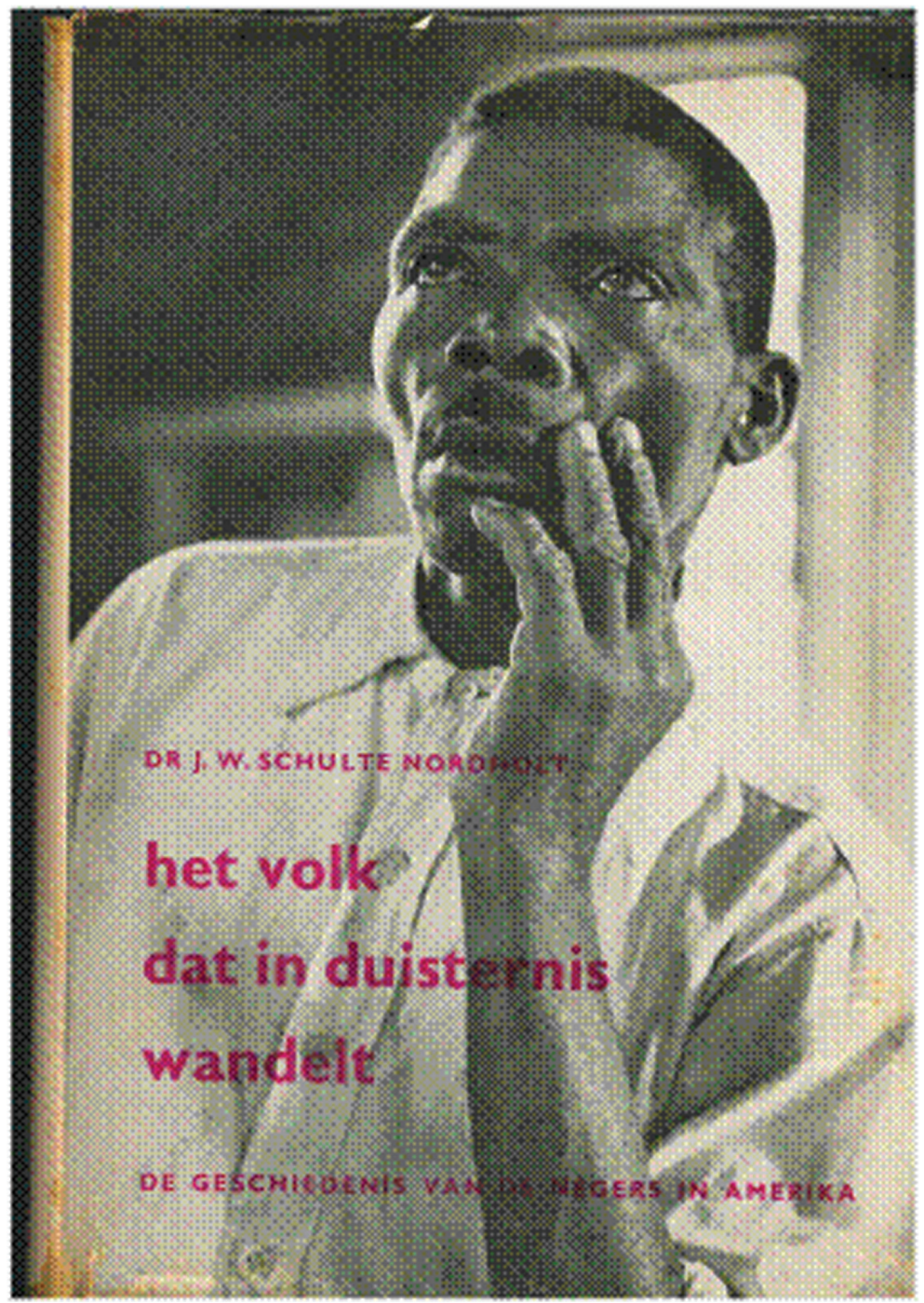

"The history of the Negroes in America is basically the story of the tension between people's great dreams and their bitter reality," according to the Protestant poet and historian Jan Willem Schulte Nordholt in Het volk dat in duisternis wandelt. De geschiedenis van de negers in Amerika (Arnhem: Van Loghum/Slaterus, 1956).

1800 , but he did not connect the narrative to the history of slavery and abolitionism in Great Britain or the Netherlands. He simply claimed that the slave trade and slavery belonged to the domain of history, even though 
there was still an "aftermath" (Roskam, 1977, 7). He then continued to say that Equiano's narrative illustrated "the past and present precariousness of black people's lives in a white-dominated world" (7), but presented the narrative first and foremost as "another book" (7) that might interest people who enjoyed Alex Haley's bestseller Roots: The Saga of an American Family (1976) - or the popular tv series (1977) based on it.

In English-speaking parts of the world, in the meantime, Equiano's narrative had risen to prominence as a major source text for post-colonial, African, and African-American Studies programs, exposing "Black agency" and "Black experience" (Walvin 1998). From the moment fragments of Equiano's narrative were published in Nigerian Perspectives: An Historical Anthology (1960), the book has been continually reprinted. Confronted with Sierra Leonese students' demands for non-British literature, literary scholar Paul Edwards edited and published an abbreviated version of the Interesting Narrative, which was published as Equiano's Travels (1966). The 1967 reprint of this edition was used for the Dutch translation introduced by Roskam, but in 1977 the full edition was widely available too. Edwards had edited and published the complete Interesting Narrative in 1969, and the text was included in African-American anthologies like Great Slave Narratives (1969). In other words, Equiano's life story had become a post-colonial, African, and African-American classic. In the Netherlands, however, Equiano's narrative was still read as a leisure book, almost as if nothing had changed between 1790 and 1977.

But something had changed. In the 1970s, post-colonial migrants from the Caribbean parts of the Netherlands brought slavery's heritage literally "home" (Oostindie). This resulted in a new reading of slave narratives, as indicated by In slavernij (In Bondage, 1983). This first Dutch translation of Harriet Jacobs"s Incidents in the Life of a Slave Girl (1861) was produced by the feminist publishing house Sara, and introduced by the Surinamese-Dutch anthropologist Philomena Essed. She reminded Dutch readers of the fact that the Netherlands had practiced slavery too, and linked the legacy of slavery to "everyday racism" in contemporary Dutch society ${ }^{15}$ In particular, she used Jacobs's slave narrative to attack racist tendencies within the women's liberation movement. According to Essed, an understanding of "the racism of then" - as described by Jacobs - could help to conquer the "present-day racism of white women towards black women" (Essed 1983, 6).

Essed's point that slavery was part of Dutch history was not taken up by critics. ${ }^{16}$ Some mentioned the historical relevance of Jacobs's "document," but slavery remained a theme largely associated with the United States. The feminist relevance, on the other hand, was taken for granted. Many reviewers repeated Essed's statements about the entanglement of 
racism and sexism, yet most responded to the "document" in a very general sense. They applauded Harriet Jacobs's narrative as "a fascinating read," "a very special" or "impressive" book, and a book of "timeless value" because it showed the courage and persistence of a "strong woman." It was hardly recognized that this "strong woman" had been a slave in a specific time and place though. Not unlike the responses to Booker T. Washington's Up from Slavery in 1902, slavery was treated as a somewhat general background of misfortune against which a "wo/man of character" could shine. Self-help and (feminist) self-emancipation, apparently, were recognizable themes in post-Protestant Dutch readings of Anglo-American slave narratives in the twentieth century - though slavery was not.

No more historical slave narratives have been translated from English into Dutch since 1983. However, in the 1990s, Caribbean migrants became more vocal in demanding public recognition of the history of colonial slavery and its legacy (Nimako and Willemsen 158-64). Huge successes were achieved in a relative short period of time: A National Slavery Monument (2002) and a National Institute for the Study of Dutch Slavery and Its Legacy (2003) were created, and the topic of colonial slavery became part of historical culture in the Netherlands. In 2013, 150 years since 1863, slavery and its abolition were celebrated and commemorated in both public and academic history events. But a recurring point of debate concerns white or Eurocentric perspectives on slavery. Critics stress that there is little room for voices and experiences of enslaved people themselves or their descendents. Responding to this, the National Institute for the Study of Dutch Slavery and Its Legacy aimed to find autobiographical narratives by slaves from the Carribean colonies. ${ }^{17}$ But given the apparent non-existence of any such documents, a recent inventory of historical source materials pointed to the narratives of Olaudah Equiano and Booker T. Washington instead (Stipriaan et al. 2007, 42, 126).

One can argue about whether Anglo-American slave narratives are of any use for the study of slavery in the Dutch colonies, but for my present purpose it is more interesting to note the remarkable fact that these narratives are connected to real-life, colonial slavery at all. Since the late eighteenth century, virtually no Dutch critic has thought of Anglo-American slave narratives as meaningful tools to discuss or reflect on the slave trade, slavery, or its legacy. On the other hand, slave narratives did make sense as sensational, gothic leisure literature, and as texts that underscored orthodox Protestant interpretations of slavery as a spiritual deprivation that called for personal and collective transformation. Only in the late twentieth century did these traditional Protestant readings give way to post-colonial interpretations stressing Black experience, Black agency, and Black subjectivity. Highly inspired by African-American rhetoric, this 


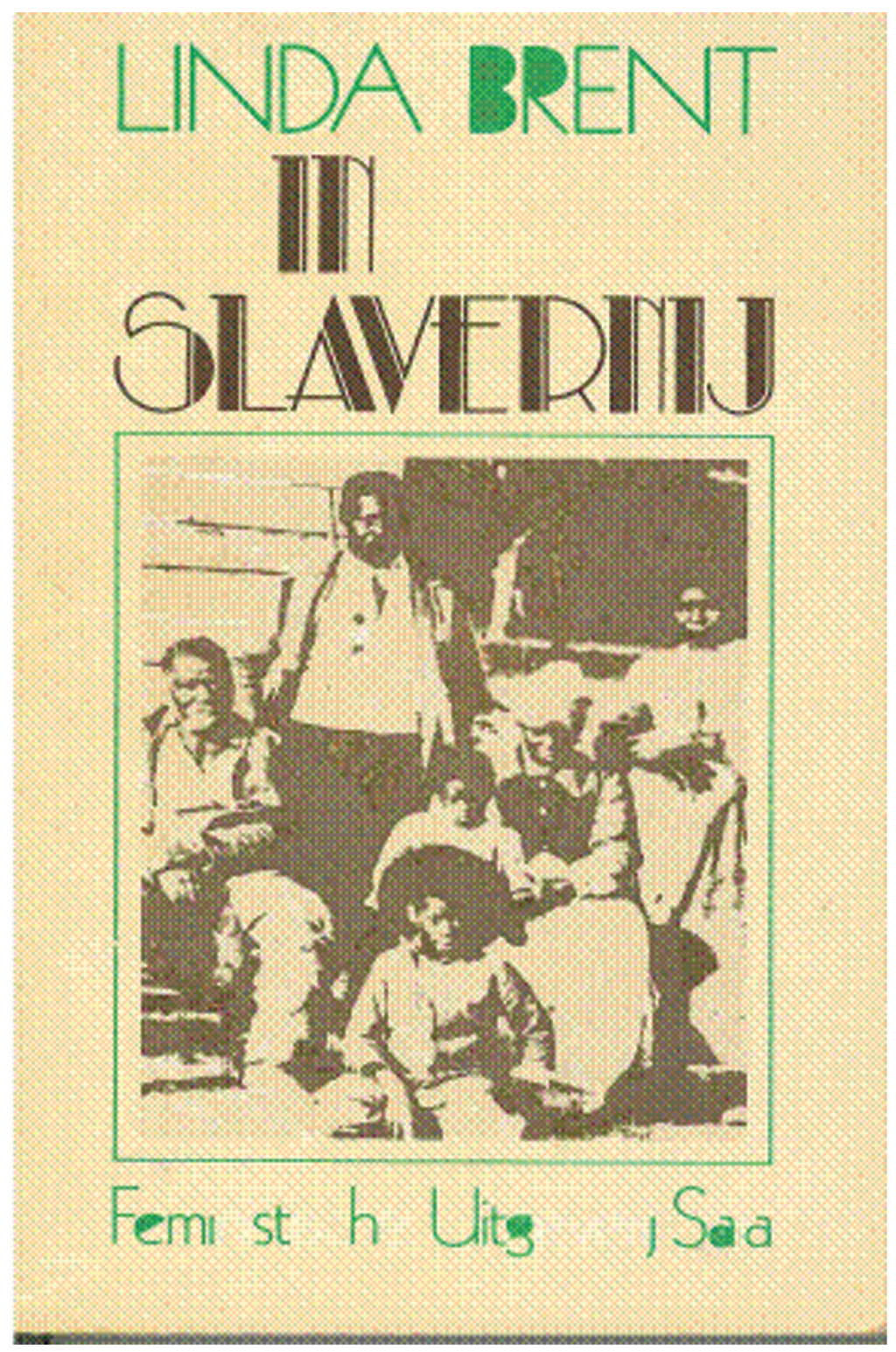

In 1983 feminist publishing house Sara launched a translation of Incidents in the life of a slave girl (1861) by Linda Brent, alias of Harriet Jacobs. 


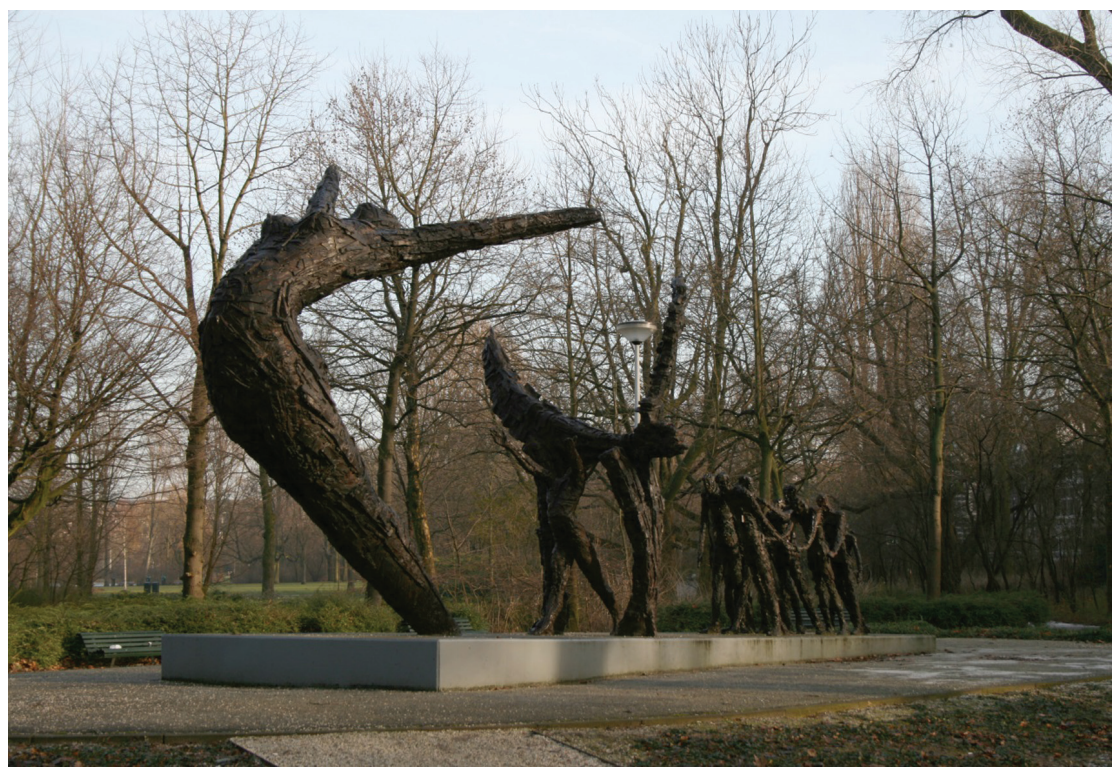

National Slavery Monument in the Oosterpark, Amsterdam. Sculptor Erwin de Vries designed the monument.

interpretation helped Afro-Caribbean migrants break the public silence on the Dutch history of slavery, create space for Blacks as human subjects, and frame historical slavery in terms of human rights. My analysis shows, however, that this reading is not a natural or given consequence of these autobiographical texts as such.

The Dutch response to slave narratives may not have been very different from the German. Heike Paul concluded her studies of German interpretations that a broad range of slavery texts were also geared towards other causes besides abolitionism. Posing that German readers were not "really" interested in slavery and the agency of Black people (Paul 2010, 162-3), however, she seems to suggest that slave narratives have some sort of intrinsic meaning, which can be appropriated in the right or wrong way. My point is rather that texts have no fixed meaning, message, or subject. Nowadays life writing critics often think that slave narratives are relevant because they enable us to encounter a Black human subject, but this understanding is clearly not given with the texts. Other people, in other times and other places, took a different stance towards the subject of slave narratives, as I have demonstrated in this analysis of Dutch readings. It seems worthwhile to take such readings seriously in order to find 
out what has changed in thinking about the subject of autobiographical narratives, and to study instead of pose under what conditions life stories can (not) be helpful tools for pursuing the equal distribution of rights to life, liberty and the pursuit of happiness.

\section{WORKS CITED}

Adama van Scheltema, C.S. "Voorrede van de vertaler." Oom Tom's Levensgeschiedenis van 1789 tot 1877, beschreven door hemzelven. Amsterdam: Het Evangelisch Verbond, 1877. xiii-xv. Print.

Andeweg, Agnes. Griezelig gewoon. Gotieke verschijningen in Nederlandse romans, 1980-1995. Maastricht: Universitaire Pers Maastricht, 2010. Print.

Andrews, William L. To Tell a Free Story. The First Century of Afro-American Autobiography, 1760 1865. Urbana/Champaign: University of Illinois Press, 1986. Print.

Andrews, William L. ed. The Oxford Frederick Douglass Reader. New York: Oxford University Press, 1996. Print.

Andrews, William L. "Introduction.” Slave Narratives after Slavery. New York: Oxford University Press, 2011. vii-xxvii. Print.

Barnet, Michael. "Saving Slaves, Sinners, Savages, and Societies." Empire of Humanity: A History of Humanitarianism. Ithaca/London: Cornell University Press, 2013.

Beecher Stowe, Harriet. "Preface." Truth Stranger than Fiction: Father Henson"s Story of His Own Life. Boston: John P. Jewett \& Company, 1858. iii-v. Print.

Brion Davis, David. Inhuman Bondage: The Rise and Fall of Slavery in the New World. Oxford: Oxford University Press, 2006.

Cohen Stuart, M. "Voorrede." Oom Tom's Levensgeschiedenis van 1789 tot 1877, beschreven door hemzelven. Amsterdam: Het Evangelisch Verbond, 1877. xxi-xxii. Print.

Carretta, Vincent, ed., Olaudah. Equiano. The Interesting Narrative and Other Writings. New York: Penguin Books, 1995. Print.

Carretta, Vincent. Equiano, the African: Biography of a Self-made Man. New York: Penguin, 2006. Print.

Carretta, Vincent. "Responses to Paul Lovejoy's Autobiography and Memory: Gustavus Vassa, alias Olaudah Equiano, the African.” Slavery E Abolition 28.1 (2007): 115-9. Print.

DeLombard, Jeannine Marie. Slavery on Trial: Law, Abolitionism, and Print Culture. Chapel Hill: University of North Carolina Press, 2007. Print.

Douglass, Frederick. Autobiographies. Ed. Henry Louis Gates, Jr. New York: Library of America, 1996. Print.

Drescher, Seymour. "The Long Goodbye: Dutch Capitalism and Anti-slavery in Comparative Perspective." Ed. Gert Oostindie. Fifty Years Later: Antislavery, Capitalism, and Modernity in the Dutch Orbit. Leiden: KITLV Press, 1995. 25-66. Print.

Eakin, Paul John. "Breaking Rules: The Consequences of Self-narration." Biography 24.1 (2001): 113-27. Print.

"Ein Sklavenleben." Ed. L.F.W. Hoffmann. Missions-Studenten. Neue Sammlung. Stuttgart: Steinkopf, 1851. 18-36. Print.

Essed, Philomena. "Inleiding." Ed. Linda Brent. In slavernij. Amsterdam: Feministische Uitgeverij Sara, 1983. 5-9. Print.

Fisch, Audrey. "Uncle Tom and Harriet Beecher Stowe in England." Ed. Cindy Weinstein, The Cambridge Companion to Harriet Beecher Stowe. Cambridge: Cambridge University Press, 2004. 96-112. Print. 
Gates, Henry Louis, ed. The Classic Slave Narratives. New York: Signet Classic, 2002 [1987]. Print.

Gould, Philip. "The Rise, Development, and Circulation of the Slave Narrative." Ed. Audrey Fisch. The Cambridge Companion to the African American Slave Narrative. Cambridge: Cambridge University Press, 2007. 11-27. Print.

Green, James. "The Publishing History of Olaudah Equiano"s Interesting Narrative." Slavery E Abolition 16.3 (1995): 362-75. Print.

Greenblatt, Stephen. "Cultural Mobility: An Introduction." Eds. Stephen Greenblatt et al. Cultural Mobility: A Manifesto. Cambridge: Cambridge University Press, 2010. 1-23. Print.

Groen, J.A. ed. Een slavenleven; of korte levensbeschrijving van eenen Amerikaanschen slaaf, door hem zelven medegedeeld. Toegift op Harriet Beecher Stowe's belangrijk werk: Uncle Tom's Cabin. Leiden: J.H. Zitman, 1853. Print.

Groen van Prinsterer, Guillaume. Handboek der geschiedenis van het vaderland. Vierde druk. Amsterdam: H. Höveker, 1875. Print.

Groningen, M. van. "Willem Teellinck en het tweede-Israëlidee." Documentatieblad Nadere Reformatie 20.2 (1996) 81-9. Print.

Hellema, Duco. Nederland en de jaren zeventig. Amsterdam: Boom, 2012. Print.

Holsteijn, Pieter. "Voorbericht van den Uitgever." Merkwaardige levensgevallen van Olaudah Equiano of Gustavus Vassa, den Afrikaan, door hemzelven beschreven. Rotterdam: Pieter Holsteijn, 1790. n.p. Print.

Houkes, Annemarie. Christelijke vaderlanders. Godsdienst, burgerschap en de Nederlandse natie, 1850-1900. Amsterdam: Wereldbibliotheek, 2009. Print.

Huisman, Marijke. "Selling the Self: Autobiographical Writing and Publishing in the Netherlands, nineteenth century." Ed. Alfred Hornung. Autobiography and Mediation. Heidelberg: Winter Verlag, 2010. 117-28. Print.

Huisman, Marijke. "Autobiography and Contemporary History: The Dutch Reception of Autobiographies, 1850-1918.” Eds. Arianne Baggerman, Rudolf Dekker and Michael Mascuch. Controlling Time and Shaping the Self: Developments in Autobiographical Writing since the Sixteenth Century. Leiden/Boston: Brill, 2011. 387-419. Print.

Huisman, Marijke. "Translation Politics: Foreign Autobiographies on the Nineteenth-century Dutch Book Market." Eds. Marijke Huisman, Anneke Ribberink, Monica Soeting and Alfred Hornung. Life Writing Matters in Europe. Heidelberg: Winter Verlag, 2012. 57-74. Print.

Huisman, Marijke. "Selves in Numbers: A Book-Historical Perspective on Nineteenth-Century Autobiography in the Netherlands." Lifewriting Annual, volume 4\&5 (2015) 201-219. Print.

Janse, Maartje. De afschaffers. Publieke opinie, organisatie en politiek in Nederland, 1840-1880. Amsterdam: Wereldbibliotheek, 2007. Print.

Jensen, Meg and Margaretta Jolly. We Shall Bear Witness: Life Narratives and Human Rights. Madison: University of Wisconsin Press, 2014. Print.

Jolly, Margaretta and Richard Jolly. [Review]. Human Rights Quarterly 28 (2006): 780-3. Print.

Kloek, J.J. and W.W. Mijnhardt. Leescultuur in Middelburg aan het begin van de negentiende eeuw. Middelburg: Zeeuwse bibliotheek, 1988. Print.

Kuitenbrouwer, Maarten. De ontdekking van de Derde Wereld. Beeldvorming en beleid in Nederland, 1950-1990. Den Haag: SDU, 1994. Print.

Kuitenbrouwer, Maarten. "The Dutch Case of Antislavery: Late and Elitist." Ed. Gert Oostindie. Fifty Years Later: Antislavery, Capitalism, and Modernity in the Dutch Orbit. Leiden: KITLV Press, 1995. 67-88. Print.

Kruseman, A.C. Bouwstoffen voor een geschiedenis van den Nederlandschen boekhandel, gedurende de halve eeuw 1830-1880. Amsterdam: P.N. van Kampen, 1886-1887. Print.

Lenders, Maria. Strijders voor het Lam. Leven en werk van Herrnhutter broeders en -zusters in Suriname, 1735-1900. Leiden: KITLV Uitgeverij, 1996. Print. 
Lovejoy, Paul E. "Autobiography and Memory: Gustavus Vassa, alias Olaudah Equiano, the African." Slavery \& Abolition 27.3 (2006): 317-47. Print.

Meijer, Annemieke. The Pure Language of the Heart: Sentimentalism in the Netherlands, 1775 1800. Amsterdam/Atlanta: Rodopi, 1998. Print.

Netscher, Frans. "Van boeken en menschen." De Telegraaf, 27 December 1902. Print.

Nichols, Charles H. "Who read the slave narratives." Phylon Quarterly 20.2 (1959): 149-62. Print.

Nimako, Kwame and Glenn Willemsen. The Dutch Atlantic: Slavery, Abolition, and Emancipation. London: Pluto Press, 2011. Print.

Norrell, Robert J. Up from History: The Life of Booker T. Washington. Cambridge: Harvard University Press, 2009. Print.

Oostindie, Gert. "History brought Home: Postcolonial Migrations and the Dutch Rediscovery of Slavery." Ed. Wim Klooster. Migration, Trade, and Slavery in an Expanding World. Leiden/Boston: Brill, 2009. 305-27. Print.

Paasman, A.N. Reinhart: Nederlandse literatuur en slavernij ten tijde van de Verlichting. Leiden: Nijhoff, 1984. Print.

Paul, Heike. "Cultural Mobility between Boston and Berlin: How Germans Have Read and Reread Narratives of American Slavery." Eds. Stephen Greenblatt et al., Cultural Mobility: A Manifesto. Cambridge: Cambridge University Press, 2010. 122-71. Print.

Pierson, Jan Lodewijk. "Voorwoord." Uit slavernij in vrijheid. Autobiographie van Booker T. Washington. Gorinchem: P.M. Wink, 1902. iii-vii. Print.

Reinsma, R. Een merkwaardige episode uit de geschiedenis van de slavenemancipatie, 1863-1963. Den Haag: Van Goor, 1963. Print.

Renders, Hans. "The Limits of Representativeness: Biography, Life writing, and Microhistory." Eds. Hans Renders and Binne de Haan, Theoretical Discussions of Biography: Approaches from History, Microhistory, and Life Writing. Lewiston: Edwin Mellen Press, 2013. Print.

Rijn, Jaap van. De eeuw van het debat. De ontwikkeling van het publieke debat in Nederland en Engeland, 1800-1920. Amsterdam: Wereldbibliotheek, 2010. Print.

Ripley, Peter. "The Autobiographical Writings of Frederick Douglass." Eds. William L. Andrews and William S. McFeely. Narrative of the Life of Frederick Douglass, an American Slave; Written by Himself; Authoritative Text, Context, Criticism. London: W.W. Norton, 1997. 136-46. Print.

Roskam, Karel. "Woord vooraf." Ed. Paul Edwards. Equiano's reizen. De autobiografie van een negerslaaf. Haarlem: Van Dishoeck, 1977. 7-8. Print.

Schaffer, Kay and Sidonie Smith. Human Rights and Narrated Lives: The Ethics of Recognition. New York: Palgrave MacMillan, 2004. Print.

Schama, Simon. Overvloed en onbehagen. De Nederlandse cultuur in de Gouden Eeuw. Amsterdam: Contact, 1989. Print.

Schulte Nordholt, Jan Willem. Het volk dat in duisternis wandelt. De geschiedenis van de negers in Amerika. Arnhem: Van Loghum Slaterus, 1956. Print.

Schutte, G.J. Het Calvinistisch Nederland. Mythe en werkelijkheid. Hilversum: Verloren, 2000. Print.

Sens, Angelie. Chapter 4: "Slavernij en vrijheid. Het maatschappelijk debat." "Mensaap, heiden, slaaf." Nederlandse visies op de wereld rond 1800. Den Haag: SDU, 2001. Print.

Sinanan, Kerry. "The Slave Narrative and the Literature of Abolition." Ed. Audrey Fish. The Cambridge Companion to the African American Slave Narrative. Cambridge: Cambridge University Press, 2007. 61-80. Print.

Sollors, Werner ed. The Interesting Narrative of the Life of Olaudah Equiano, or Gustavus Vassa, the African, Written by Himself. New York/London: W.W. Norton, 2001. Print. 
Starling, Marion W. The Slave Narrative: Its Place in American History. Washington, DC: Howard University Press, 1988. Print.

Stipriaan, Alex van, Waldo Heilbron, Aspha Bijnaar and Valika Smeulders. Op zoek naar de stilte. Sporen van het slavernijverleden in Nederland. Leiden/Amsterdam: KITLV Uitgeverij/ NiNsee, 2007. Print.

Walvin, James. "Chapter 15: Fall, Decline - and Rediscovery." An African"s Life: The Life and Times of Olaudah Equiano, 1745-1797. London/New York: Cassell, 1998. Print.

Washington, Booker T. Up from Slavery: An Autobiography. New York: Doubleday \& Company, 1901. Print.

Whitlock, Gillian. Soft Weapons: Autobiography in Transit. Chicago: University of Chicago Press, 2007. Print.

Willemsen, Glenn. Dagen van gejuich en gejubel. Viering en herdenking van de afschaffing van de slavernij in Nederland, Suriname en de Nederlandse Antillen. Amsterdam/Den Haag: NiNsee/ Amrit, 2006. Print.

Williams, James. Narrative of James Williams, an American Slave, Who Was for Several Years a Driver on a Cotton Plantation in Alabama. Boston: American Anti-Slavery Society/Isaac Knapp, 1838. Print.

\section{ABOUT THE AUTHOR}

Marijke Huisman (1972) teaches at the History departments of Utrecht University and VU University Amsterdam. She conducted her research into the transnational production and reception of slave narratives as post-doctoral researcher (2009-2013) at the Center for Historical Culture at Erasmus University Rotterdam and visiting scholar at the University of California, Berkeley. She co-organised the first IABA Europe conference (2009) and co-edited the volume Life Writing Matters in Europe (Heidelberg: Universitätsverlag Winter, 2012).

\section{NOTES}

1 See also William L. Andrew's introduction to the full-text collection "North American Slave Narratives" at the "Documenting the American South" website of the University of North Carolina, Chapel Hill: http://docsouth.unc.edu/neh/.

2 Anonymous, Review of B.J. Frossard, De zaak der Negerslaaven en der Inwooneren van Guinea ... (Den Haag 1790). Algemeene Vaderlandsche Letter-Oefeningen (1791) 601-602.

3 Anonymous, Review. Vaderlandsche bibliotheek van Wetenschap, Kunst en Smaak (1791) 123$129,129$.

4 Advertisement. Nieuwsblad voor den boekhandel, 3 December 1846.

5 "Letterkundige Berigten". Bijdragen tot de kennis der Nederlandsche en vreemde koloniën, bijzonder betrekkelijk de vrijlating der slaven (1847) 102-109.

6 Reviews are online available through: http://docsouth.unc.edu/neh/douglass/.

7 [Review] from Lynn Pioneer, reprinted in The Liberator, 30 May 1845; Margaret Fuller, "Review of Narrative of the Life of Frederick Douglass". New York Tribune, 10 June 1845.

8 Anonymous, [Review]. De Recensent, ook der recensenten (1847) 306-307.

9 Levensgeschiedenis van den Amerikaanschen slaaf W. Wells Brown, Amerikaansch afgevaardigde bij het Vredescongres te Parijs, 1849, door hem zelven beschreven (Zwolle: Tjeenk Willink, 1850); Een slavenleven; of korte levensbeschrijuing van eenen Amerikaanschen slaaf, door hem zelven 
medegedeeld. Toegift op Harriet Beecher Stowe's belangrijk werk: Uncle Tom's Cabin (Leiden: J.H. Zitmann, 1853); John Passmore Edwards ed., De lotgenooten van Oom Tom, of waarheid erger dan verdichting, treffende tooneelen uit het leven van beroemde gevluchte slaven (Middelburg: J.C. en W. Altorffer, 1854); Slavenleven in Georgië, een verhaal van het leven, lijden en ontkomen van John Brown, een" gevluchten slaaf, nu in Engeland (Amsterdam: H.A. van Helden, 1856).

10 Publisher's note. Levensgeschiedenis van den Amerikaanschen slaaf W. Wells Brown. Door hem zelven beschreven (Zwolle: W.E.J. Tjeenk Willink, 1850) n.p.

11 Advertisement. De Standaard, 3 december 1877.

12 [Review]. De Nederlandsche Spectator, 7 maart 1903, 74.

13 B., "Boek (over negers in VS) dat niet meer loslaat". Friese Koerier, 24 December 1956; Peter van Steen, "Boeken van en over negers, als een waaier der bitterheid, eindeloos gevarieerd". Het vrije volk, 2 Juni 1961.

14 B., "Boek (over negers in VS) dat niet meer loslaat".

15 Philomena Essed became renowned for her works on "everyday racism": Everyday Racism: Reports of Women of Two Cultures (Alameda: Hunter House, 1990) and Understanding Everyday Racism: An Interdisciplinary Theory (Newbury Park: Sage, 1991).

16 Folder of reviews, Archive Feministische Uitgeverij Sara (60), Atria, Kennisinstituut voor Emancipatie en Vrouwengeschiedenis, Amsterdam, the Netherlands.

17 Website NiNsee, http://www.ninsee.nl/Projecten, 29 november 2011. 